\title{
LOS GRANDES TEMAS DEL PENTATEUCO Y LOS PROFETAS*
}

\section{Introducción}

El dato más importante que ha sorprendido a los exegetas desde el inicio de la lectura crítica de la Biblia es el silencio de los profetas, sobre todo de los profetas pre-exílicos, respecto de los grandes temas del Pentateuco. Retomo algunos ejemplos más llamativos. Abraham, por ejemplo, nunca es mencionado en Amós, Oseas, Miqueas, ni en los textos más antiguos del profeta Isaías, ni en el libro de Jeremías. Encontramos su nombre en un texto difícil de datar; se trata de Is 29,22. Lo hallamos después en el así denominado segundo Isaías, en Is 48,8; 51,2, y en Ez 33,24.

La teofanía del Sinaí, por tomar otro ejemplo notable, parece ser para el Pentateuco la bisagra de la historia del pueblo. Pues bien, ningún profeta habla de ella. Jr 31 habla de la nueva alianza, pero no alude en modo alguno al Sinaí. Ez 20 contiene un largo oráculo sobre la permanencia de Israel en el desierto y no dice una palabra sobre el Sinaí o sobre una alianza en el desierto. Este asunto sorprende no poco porque, en ambos ejemplos, el lector moderno esperaría de hecho una alusión al Sinaí. ¿Por qué Jeremías no dice que la nueva alianza renueva la del Sinaî? ¿Por qué Ezequiel, cuando condena al Israel rebelde desde Egipto y desde el desierto, no dice que el pueblo no respetó la alianza celebrada de manera solemne en el Sinaí? Es difícil descartar la sospecha de que ni Jeremías ni Ezequiel conocieron el relato de la teofanía del Sinaí. Surge también de inmediato la hipótesis de que la sección de Ex 19-24 sea probablemente más reciente que Jr 31 y Ez 20.

* El presente artículo fue presentado como conferencia en la I Semana Bíblica Argentina, que tuvo lugar en Buenos Aires del 26 al 28 de mayo de 2011. 
Podríamos añadir otros ejemplos. Menciono solo dos. De Noé sólo hablan Ez 14,14-20 -pero sin hablar del diluvio-e Is 54,9, esta vez con una alusión clara al diluvio. De la historia de José no encontramos rastros en los libros proféticos. Se habla solo de José como pueblo (vale decir, el reino del norte: Ez 37,19; 47,13; Am 5,6.15; 6,6; Ab 1,18; Za 10,6).

¿Cómo explicar esto? Es el objetivo de esta breve investigación que nos permitirá releer algunas páginas importantes del Antiguo Testamento y asistir, por así decirlo, al nacimiento del Pentateuco en compañía de los grandes profetas. Mi punto de vista es por lo tanto histórico. Partiré de los textos más antiguos, apoyándome en los resultados más seguros y más sólidos de la exégesis moderna para llegar a los textos más recientes. Me limitaré a los textos y a los temas más importantes y dejaré de lado las alusiones a episodios secundarios y a textos particulares.

\section{Amós y Oseas}

\subsection{Amós (hacia el 750 a.C. - reino del Norte)}

El profeta Amós -en cuanto podemos obtener en el libro de Amós oráculos antiguos que se remontan al período pre-exílico- habla sobre todo del éxodo (la salida de Egipto), de la permanencia en el desierto y de la conquista de la tierra. Encontramos alusiones a estos tres momentos del pasado de Israel, precisamente en un oráculo contra el reino del Norte (Am 2,6-16). He aquí el texto más importante (Am 2,9-10):

${ }^{9}$ Yo había destruido al amorreo delante de ellos, que era alto como la altura de los cedros y fuerte como las encinas; yo había destruido su fruto por arriba y sus raíces por abajo. ${ }^{10} Y$ yo los hice salir a ustedes de la tierra de Egipto y los conduje por el desierto cuarenta años, para que poseyeran la tierra del amorreo.

Encontramos alusiones a la salida de Egipto de nuevo en Am 3,1:

Escuchen esta palabra que dice Yahveh contra ustedes, hijos de Israel, contra toda la familia que yo hice salir de la tierra de Egipto.

Y también en Am 9,7:

¿No son ustedes para mí como hijos de etíopes, hijos de Israel? -oráculo de Yahveh- ¿No hice yo salir a Israel de la tierra de Egipto, como a los filisteos de Kaftor y a los arameos de Quir?

Se lee una alusión a la permanencia en el desierto en Am 5,25:

¿Acaso sacrificios y oblaciones en el desierto me ofrecieron durante cuarenta años, casa de Israel? 
En resumen, Amós, que predica en el reino del Norte, no habla nunca de los patriarcas. Habla sólo de tres acontecimientos o tres momentos importantes: la salida de Egipto, la permanencia en el desierto y la entrada en la tierra prometida. Las alusiones son muy sobrias y, además, no podemos decir mucho sobre el contenido de estas tradiciones. No se habla, por ejemplo, de las plagas de Egipto (Ex 7-12) o del milagro del mar (Ex 14). La permanencia en el desierto duró cuarenta años, pero no se dice nada sobre las condiciones de vida allí, salvo que el culto era muy sencillo y no comportaba muchos sacrificios. Al final, la conquista de la tierra menciona la presencia de los amorreos en el país.

Estos tres momentos son importantes para Amós porque le permiten establecer cuáles son los deberes de Israel respecto a su Dios. La libertad y la tierra son dos dones de Dios. Además, Amós recuerda al pueblo tres datos importantes de su tradición: estuvo en Egipto, estuvo en el desierto y la tierra que ocupa ahora no siempre fue suya. Podemos pensar, por lo tanto, que el núcleo más antiguo -o al menos, uno de los núcleos más antiguosdel Pentateuco sea precisamente el éxodo, unido a la permanencia en el desierto y después a la toma de posesión de la tierra.

\subsection{Oseas (hacia 740-730 a.C. - reino del Norte)}

Oseas parece confirmar esta primera impresión. Añade, sin embargo, un elemento nuevo y muy importante, como veremos.

Hay algunas alusiones evidentes al éxodo y al desierto en los primeros capítulos de Oseas. La primera se encuentra en Os 2,17, en el célebre proceso a la mujer infiel:

${ }^{16}$ Por eso yo voy a seducirla; la llevaré al desierto y hablaré a su corazón.

${ }^{17}$ Allí le daré sus viñas, el valle de Akor lo haré puerta de esperanza; y ella responderá allí como en los días de su juventud, como el día en que salió de la tierra de Egipto.

Oseas, a la par de Amós, habla de la salida de Egipto y alude a la permanencia en el desierto. Otras alusiones a Egipto están presentes en 9,3; $11,1.5 ; 12,10.14 ; 13,4-6^{1}$. De estos textos vale la pena citar al menos Os 12,10 :

Yo soy Yahveh, tu Dios, desde el país de Egipto: aún te haré morar en tiendas como en los días de solemnidad.

1 Os 9: "Ellos no habitarán en la tierra del Señor, sino que Efraím volverá a Egipto y a Asiria, comerán alimentos impuros" - Efraím volverá a Egipto, lo que significa que allí había estado antes. Os 11: "Cuando Israel era niño, yo lo amé y llamé a mi hijo desde Egipto", texto citado por Mateo 2,15. Os 11,5a: "Israel no volverá al país de Egipto". Os 12: "Pero yo soy el Señor, tu Dios, desde el país de Egipto; yo te haré 
El texto es importante por un motivo principal. Habla evidentemente del éxodo. Pero el punto importante es la afirmación de que Yhwh, el Señor, es el Dios de Israel desde los tiempos del éxodo. El verdadero inicio de la historia de Israel coincide con el éxodo y la permanencia en el desierto. No son la posesión de la tierra y sus consecuencias. El final de la frase: "aún te hare morar en tiendas, como en los días de solemnidad" puede significar más cosas. La palabra traducida como "solemnidad" puede significar "tiempo determinado", "asamblea", "celebración”. La interpretación más razonable ve en este verso una crítica al modo de vivir actual de un Israel que se enriquece gracias al comercio y olvida el ideal del desierto. Los grandes de Israel viven en palacios, la sociedad se preocupa sobre todo de problemas económicos y comerciales. El Señor quiere hacer volver a todo el pueblo al desierto para volver a vivir en la sencillez y en la autenticidad. Como tiempo paradigmático y punto de referencia para Israel permanece el éxodo y el desierto, no la posesión de la tierra y las nuevas condiciones económicas que de ella resultan. Israel es más antiguo que la posesión de la tierra y no debe olvidar sus orígenes si no quiere correr el riesgo de desaparecer.

En este contexto, Os 12,14 introduce incluso la figura de un profeta que no puede ser sino Moisés. La figura de Moisés aparece para crear un contraste con otra figura que emerge también por primera vez en este texto de Oseas: el patriarca Jacob. Jacob es visto aquí como figura negativa, mientras que el profeta-Moisés- es presentado como modelo positivo. Jacob es el antepasado de un pueblo "engañador" y desleal (12,1-2; cf. 12,12), que piensa sólo en enriquecerse $(12,9)$ y en perpetuar el propio nombre. El profeta, en cambio, está preocupado por la suerte de todo el pueblo del cual se comporta como el "guardián" $(12,14)$. El contraste es fuerte, en verdad, pero nos permite comprender mejor qué se conocía de Jacob y de Moisés en la época de Oseas.

De la historia de Jacob, Oseas cita un cierto número de episodios que se hallan en el libro del Génesis. Significa que tenemos ya en el libro

aún habitar en tiendas, como en los días de solemnidad"; el texto contiene alusiones a la salida de Egipto y a la permanencia en el desierto. Os 12: "Mediante un profeta el Señor condujo a Israel fuera de Egipto; Israel fue cuidado por un profeta" - otras alusiones a la salida de Egipto y a la permanencia en el desierto. La segunda alusión, como en Os 12,10b, es menos explícita. Os 13,4: “Sin embargo, yo soy el Señor, tu Dios, desde el país de Egipto; tú no debes reconocer otros dioses fuera de mí, porque fuera de mí no hay otro salvador. Yo te conocí en el desierto, en el país de la gran aridez. Cuando hubo pastos, se saciaron; cuando estaban saciados, su corazón se ensoberbecía; por eso me olvidaron". 
de Oseas rasgos de un "ciclo" de relatos. Los principales episodios citados son los siguientes:

1. El nacimiento y la rivalidad con el hermano (Esaú): Os 12,4aGn 25,26.

2. La lucha contra Dios: Os 12,4b-5a - Gn 32,24-28.

3. El encuentro con Dios en Betel: Os 12,5b - Gn 28,10-22.

4. La fuga de Jacob hacia Aram y su matrimonio: Os 12,13 - Gn 29.

Los episodios citados pertenecen todos al ciclo de Jacob, pero no se puede adivinar cuál es el vínculo que los une. ¿Por qué Jacob debe huir a Aram en Os 12,13? Los destinatarios de Oseas lo sabían, probablemente, pero no se da la razón. El libro del Génesis ofrece una explicación: Jacob huye a donde su tío Labán después de apoderarse de la bendición paterna de una manera dolosa y deshonesta (Gn 27). Pero no sabemos si Oseas conocía este episodio. Podemos incluso pensar que si lo hubiese conocido, muy probablemente lo habría utilizado para condenar a un Jacob desleal e inicuo, antepasado y modelo de un pueblo que se comporta del mismo modo para alcanzar su fines.

Es precisamente de "mentira", "engaño" (en hebreo: mirmâ) que habla el texto de Os 12, primero en Os 12,1 y una segunda vez en 12,8, donde se habla de Canaán. Esta palabra es un término clave del relato de Gn 27. Aparece en la boca de Esaú en Gn 27,35 para caracterizar el comportamiento de Jacob. El término reaparecerá en Gn 29,25 cuando Jacob, a su vez, será "engañado" por su tío. Si Oseas hubiese conocido estos textos, muy probablemente los habría utilizado en su argumentación. Podemos pensar, por lo tanto, que Gn 27 aún no formaba parte del ciclo de Jacob en la época de Oseas.

Las alusiones al éxodo y a la permanencia en el desierto siguen siendo muy vagas y son mucho más generales que las de la historia de Jacob. También aquí podemos asombrarnos de no encontrar alguna alusión a la alianza del Sinaí. La alianza del Sinaí habría suministrado a Oseas argumentos fuertes para condenar el comportamiento de Israel. No es el caso; y es difícil pensar que Oseas hubiese a propósito ignorado tal tradición. Es más simple pensar que no existía aún en su tiempo.

Por cuanto respecta al Pentateuco, podemos extraer tres consecuencias de la lectura de Oseas 12. Primera, existían ya en la época de Oseas tradiciones sobre Jacob y sobre el éxodo y la permanencia en el desierto; Moisés era ya conocido. Segunda, las tradiciones conocidas por Oseas son diversas de las que encontramos ahora en el Pentateuco. El "Pentateuco" de Oseas, si podemos expresarnos de esa manera, no contiene algunos 
elementos importantes del Pentateuco tal como lo conocemos hoy por hoy. Tercera -y es importante-, el texto de Oseas 12 no crea ningún vínculo entre Jacob y Moisés, entre el patriarca y el éxodo. No habla de las promesas hechas a los patriarcas o al patriarca, no habla de su descenso a Egipto y no ve en el éxodo ningún cumplimiento de una promesa hecha a los padres. No se sabe cuál es el nexo entre Jacob y sus descendientes y el Israel que salió de Egipto.

\section{Miqueas (hacia 740-730 a.C. - reino del Sur)}

Con el profeta Miqueas dejamos el reino de Samaría y sus grandes centros comerciales para ir al profundo sur, en el campo de Judá, a Moreset, una pequeña ciudadela a unos cuarenta kilómetros, al sudeste de Jerusalén, cerca de Laquis. Miqueas refleja la mentalidad de los grandes propietarios agrarios del campo de Judea. Se siente en sus profecías un cierto resentimiento contra la capital, Jerusalén, y contra los hombres de poder que explotan los campos y se apoderan de las tierras cultivables (ver, por ejemplo, Mi 2,2). Miqueas es el primer profeta que anuncia el final de Jerusalén:

Por ello, a causa de ustedes, Sión será arada como un campo. Jerusalén se convertirá en un montón de ruinas, y el monte del templo una altura boscosa. (Mi 3,12)

Mi 6,3-5 es el texto que nos interesa, por ser más afín, si bien es difícil de interpretar y, sobre todo, difícil de datar. He aquí el texto:

${ }^{3}$ Pueblo mío, ¿qué te he hecho? ¿En qué te he molestado? Respóndeme. ${ }^{4} ¿$ En que te hice subir del país de Egipto, y de la casa de servidumbre te rescaté, y mandé delante de ti a Moisés, Aarón y María? ${ }^{5}$ Pueblo mío, recuerda, por favor, qué maquinó Balaq, rey de Moab, y qué le contestó Balaam, hijo de Beor, desde Sittim hasta Guilgal, para que conozcas la justicia de Yahveh.

Ante todo, como ya dije, los exegetas dudan de la autenticidad del oráculo. No parece pertenecer a los estratos más antiguos del libro de Miqueas. Las razones son dos. Primera, el profeta Miqueas se dirige principalmente a las clases dirigentes del reino de Judá, mientras en 6,3-5, se dirige a todo el pueblo y no parece ni siquiera distinguir entre el reino del Norte y el reino del Sur. Segunda, el oráculo permanece del todo aislado en el contexto de los capítulos 6 y 7. Mi 6,9-15, por ejemplo, es un oráculo que condena la injusticia y el engaño que reinan entre los ricos habitantes de la ciudad, y se piensa de inmediato en Jerusalén.

¿Qué fecha proponer? No hay muchos asideros sólidos para proponer una fecha bien precisa. Hay, sin embargo, algunos elementos útiles. 
Vocabulario y temáticas están presentes en algunos textos del Deuteronomio (Dt 5,6; 7,8). Se trata sobre todo del modo de describir el éxodo como "rescate" y de la expresión "casa de servidumbre". Se piensa también en un texto de estampa deuteronomística como 1 Sam 12,6. Podemos proponer como fecha el final del exilio y el primer retorno. Podríamos añadir que había llegado a ser más normal hablar de éxodo en el momento del "nuevo éxodo", es decir, al retorno del exilio. Pero se trata sólo de una propuesta. De todos modos, el oráculo es más reciente que los otros oráculos del libro de Miqueas.

¿Qué podemos extraer del oráculo? Dos elementos importantes. El primero nos confirma en nuestra investigación: el éxodo es el momento importante de la historia de Israel, el gozne de su identidad. Al éxodo están asociadas diversas figuras. Miqueas habla de Moisés, como hacía ya Oseas, pero de manera anónima. Mi 6,4 añade a Aarón y María, el hermano y la hermana que encontramos de nuevo juntos, por ejemplo, en Nm 12,1-15.

El segundo elemento es más sorprendente. Hallamos en Mi 6,5 uno de los pocos textos que hablan de Balaq y de Balaam, fuera de Nm 22-24. Además, Balaam es visto de manera positiva. Balaam es un personaje que conocemos ahora gracias a algunos textos, por desgracia bastante oscuros, encontrados en Deir'Alla, en Transjordania y que se remontan, con toda probabilidad, al 700 a.C. Los textos están escritos en arameo. Uno de los pocos sumarios de la historia de Israel que cita a Balaam y Balaq es Jos 24,9-10. Jos 24 sin embargo es considerado por la mayoría de los estudiosos actuales como un texto muy reciente. ¿Por qué citar a Balaam en Mi 6,5 ? Sólo podemos hacer conjeturas. Quizás se trata de un ejemplo particular de protección divina contra un enemigo potente. O bien se trata de un episodio significativo que precede inmediatamente la entrada en la tierra prometida, entrada que ninguno alcanza a impedir, ni siquiera Balaq, rey de Moab. ¿O bien, tal vez el oráculo fue escrito en un momento de tensión con Moab? No lo sabemos. Lo único cierto es que el oráculo quiere refrescar la memoria de Israel en un momento en el cual la emprende con su Dios y le reprocha -presumiblemente- haberlo abandonado o no haber actuado a su favor. La respuesta -y es el punto que quiero subrayar- es la "historia", en particular el éxodo, pero también un episodio particular de la permanencia en el desierto, la intervención de Balaam. Añado que el tiempo de la permanencia en el desierto es visto de modo positivo, en Miqueas 6 así como en Amós y Oseas. No se habla nunca de "rebeliones en el desierto". 


\section{Jeremías (hacia 627-580 a.C. - reino del Sur)}

Jeremías nos mueve a dar un gran paso hacia adelante. Nos encontramos en el reino del Sur, en el período más dramático de su historia. El profeta Jeremías es, de hecho, el profeta que vio derrumbarse todo aquello que se pensaba absolutamente invulnerable e inviolable: la ciudad de Jerusalén, el templo de Yhwh y la dinastía de David. Lo impensable, sin embargo, sucedió: la ciudad de Jerusalén fue conquistada, incendiada y saqueada, el templo fue destruido y el último rey de Judá fue hecho prisionero y conducido en exilio a Babilonia.

En estas circunstancias, ¿Cuáles son los grandes temas del Pentateuco usados por Jeremías en su predicación? Habla sobre todo del éxodo, que es, indiscutiblemente, la tradición preferida por los profetas, desde Amós en adelante. Jeremías habla también de la permanencia en el desierto, tema muy ligado al éxodo; luego, del don de la tierra. La vida en el desierto es vista de manera positiva, así como sus predecesores, Amós y Oseas. El tiempo ideal de la historia de Israel es precisamente el tiempo en el cual el pueblo vivía en el desierto, en la sencillez y en la cercanía de su Dios. El texto es bastante conocido (Jer 2,1-7):

${ }^{1}$ Entonces me fue dirigida la palabra de Yahveh en estos términos: ${ }^{2}$ Ve y grita a los oídos de Jerusalén: Así dice Yahveh: De ti recuerdo tu cariño juvenil, el amor de tu noviazgo; aquel seguirme tú por el desierto, por la tierra no sembrada. ${ }^{3}$ Consagrado a Yahveh estaba Israel, primicias de su cosecha. «Quienquiera que lo coma, será reo; mal le sucederá»-oráculo de Yahveh-. ${ }^{4}$ Escuchen la palabra de Yahveh, casa de Jacob, y todas las familias de la casa de Israel. ${ }^{5}$ Así dice Yahveh: ¿Qué encontraban sus padres en mí de torcido, que se alejaron de mí, y yendo en pos de la vanidad se hicieron vanos? ${ }^{6}$ En cambio no dijeron: « ¿Dónde está Yahveh, que nos subió de la tierra de Egipto, que nos llevó por el desierto, por la estepa y la paramera, por tierra seca y sombría, tierra por donde nadie pasa y en donde nadie se asienta? ${ }^{7}$ Luego los traje a la tierra del vergel, para comer su fruto y su bien. Ustedes llegaron y ensuciaron mi tierra, y hicieron de mi heredad una abominación.

Jeremías recuerda, por tanto, el éxodo, la permanencia en el desierto y el don de la tierra. En verdad, los pormenores son pocos, pero el profeta insiste mucho sobre el hecho de que durante todo el tiempo de la permanencia en el desierto, el Señor nunca negó a su pueblo su asistencia y su protección. Antes bien, dice el profeta, ¡ay de quien osara tocar a Israel! No se habla aún de rebeliones en el desierto. La infidelidad y la apostasía inician solo cuando el pueblo entra en la tierra. En este punto, Jeremías sigue a Oseas y a Amós. El asunto cambia radicalmente con Ezequiel. Valdría la pena citar con más amplitud a Jeremías para comprobar cuánto 
cambia la atmósfera cuando se pasa al profeta siguiente que predica precisamente durante el exilio ${ }^{2}$.

\section{Ezequiel (reino del Sur - Babilonia - profeta a partir del 587 a.C., aproximadamente)}

\subsection{Ezequiel 20}

Ezequiel es un poco posterior a Jeremías pero no parecen haberse conocido. ¿O quizás se ignoran? Jeremías no estaba muy ligado al templo (cf. Jr 26; ver también Jr 7), mientras Ezequiel, que era sacerdote del templo, tenía una visión diversa de las cosas.

Con toda probabilidad, Ezequiel fue deportado a Babilonia después del primer asedio de Jerusalén en el 598/597 a.C. El rey Joaquín fue arrestado, la ciudad, según las convenciones de la época, fue perdonada, pero el rey, la corte y una parte de la población debieron ir al exilio. Ezequiel formaba parte de este grupo, al menos, según gran parte de los estudiosos.

Un texto nos interesa más que los demás, se trata de Ez 20, un largo resumen de la historia de Israel. A la saga de sus predecesores, Ezequiel habla del éxodo, de la permanencia en el desierto y de la entrada en la tierra. Pero, con una diferencia esencial: toda la historia de Israel, desde el inicio, desde la permanencia en Egipto, ha sido una historia de infidelidad y de rebeliones contra Dios, el Señor de Israel. Israel ya era idólatra en Egipto $(20,8)$. Israel luego se rebeló en el desierto $(20,13.21)$ y rechazó vivir según las leyes y los decretos del Señor, en particular la ley del sábado. Es la primera vez que se habla explícitamente de una ley promulgada en el desierto. Pero no se dice que fuera promulgada en el monte Sinaí y no se habla tampoco de una alianza celebrada por Dios con su pueblo. Otra ausencia que asombra: Ezequiel no menciona nunca a Moisés. En la literatura bíblica rige el principio de la economía. En otras palabras, los escritores dicen sólo aquello que es necesario y no añaden detalles superfluos. La ausencia de Moisés nos sorprende aún más porque estamos habituados a asociar la ley al nombre de Moisés. Debemos decir que quizás en la época de

\footnotetext{
${ }^{2}$ No hablo aquí de Jeremías $16,14-16$ y 23,7-8, dos oráculos posteriores que introducen una comparación entre el éxodo y el retorno del exilio. Son oráculos más tardíos que se remontan al período pos-exílico. Jeremías habla también de Raquel, esposa de Jacob $(J r 31,15)$. La tumba de Raquel se encontraba a poca distancia de Jerusalén. La tradición era, por tanto, conocida. Pero Jeremías no desarrolla la figura de Raquel.
} 
la redacción de Ez 20 no era aún una tradición suficientemente consolidada. Dios da la ley directamente al pueblo, sin que sea necesaria ninguna mediación.

La rebelión y la idolatría continúan, ciertamente, en el país después de haber entrado allí (Ez 20,28-29). También aquí la tradición ulterior distinguirá entre el tiempo de Josué, una especie de edad de oro en la cual Israel fue fiel a su Dios, y el tiempo de los jueces que fue un tiempo de infidelidad crónica, si podemos hablar así.

¿Por qué Ez 20 ofrece un retrato tan sombrío de la historia de Israel? La razón es obvia: es la experiencia del exilio. Ezequiel, de ese modo, quiere justificar el exilio y encuentra la razón de ello en el carácter rebelde de Israel. Hoy diríamos que la rebelión forma parte de su ADN. Más importante, sin embargo, es la voluntad de Ezequiel de justificar a Dios. El exilio es culpa del pueblo, no es culpa de un Dios demasiado débil. Dios tiene razón al castigar a su pueblo, rebelde desde el inicio de su historia. Dios en cambio ha sido paciente. No se ha enfadado por una culpa reciente y aislada. Al contrario.

Hay otro punto, aún más importante, si bien es muy paradójico: si el castigo de Israel es obra de Dios, la salvación es posible. De hecho, si el exilio fuese causado por la debilidad del Dios de Israel, se debería esperar la salvación de los dioses babilonios más potentes. Si por el contrario, la destrucción del templo y de la ciudad santa fue querida y realizada por el Dios de Israel, el mismo Dios puede cambiar la suerte del pueblo. Es Él y sólo Él el dueño de la situación. En todo caso, para usar el vocabulario del profeta Ezequiel, Dios manifiesta siempre su santidad, cuando castiga y cuando salva (cf. Ez 20,41-44) ${ }^{3}$. El lenguaje es, evidentemente, sacerdotal.

Un detalle del texto es interesante, pero también enigmático. Ezequiel habla de la alianza que Dios convencerá a Israel de respetar (Ez 20,37). No hay detalles y es casi imposible decir de cuál alianza se trata.

La comparación con los otros profetas es instructiva sobre un punto principal. Ezequiel insiste mucho sobre la "ley". El texto del capítulo habla a menudo de "decretos" y de "mandamientos" (cf. 20,11.13.16.18.19.21. 24.25). El mismo vocabulario es común en el Deuteronomio. Ezequiel es

3 Sobre la santificación, obra de Dios, en Ez 20, ver 20,12.41; ver también $20,20.40$, donde aparece la raíz “santo". Por otra parte, el verbo "profanar" aparece con frecuencia en el mismo capítulo: 20,9.13.14.16.21.22.24.39. El capítulo introduce un fuerte contraste entre Yhwh, el Dios que "santifica" y el pueblo que "profana". 
el primer profeta que une, de manera tan clara, historia de Israel y "ley" (cf. Dt 4,1.45; 5,1; 6,1; 7,11; 11,32; 12,1; 26,16). Para Ez 20, la ley fue dada en el desierto, pero no se habla del Sinaí. Vale la pena insistir en el tema. Ni Oseas ni Jeremías han hablado de leyes, mandamientos o decretos promulgados por Dios en el desierto.

En conclusión, Ezequiel es fiel a la tradición profética porque insiste en la importancia del éxodo y de la permanencia en el desierto. Da, sin embargo, una connotación negativa a toda la historia, desde los primerísimos momentos. Además, introduce la idea de una legislación dada por Dios al pueblo de Israel en el desierto. Por último, Ezequiel no menciona ni a Moisés (cf. Os 12,13) ni a Aarón.

\subsection{Ezequiel 33,23-29}

Habíamos hablado de Ez 33,23-29 a propósito de Abraham. Ez 33,24 es el único texto de Ezequiel que menciona a Abraham. Pero el patriarca es utilizado por los "habitantes de las ruinas" para justificar sus reivindicaciones. Vemos claramente que el patriarca no pertenece a las tradiciones usadas por Ezequiel. Para él, es el éxodo el que cuenta, no los patriarcas. Sobre este punto Ezequiel se vuelve a encontrar en verdad en compañía de Oseas, que no tiene mucha simpatía por Jacob.

Conclusión. Podemos decir que para Ezequiel existe una tradición sobre el éxodo, sobre la permanencia en el desierto -lugar de la primera legislación de Israel- y sobre el don de la tierra. Pero las tradiciones pueden ser interpretadas de manera particular según las circunstancias y es quizás el punto más importante de nuestra investigación. Ezequiel no busca transmitir las tradiciones antiguas sobre los orígenes del pueblo. Busca convencer al pueblo de que Yhwh tiene razón al castigarlo como ha hecho. Pero el mismo Dios manifestará su poder y su "santidad" cuando haga volver al pueblo del exilio. Las antiguas tradiciones, en otras palabras, eran "medios" explotados para alcanzar ciertos objetivos. Debemos ser prudentes antes de extraer conclusiones demasiado rápidas a partir de los textos proféticos. Los profetas, Ezequiel en particular, mencionan sólo aquello que les resulta útil. Lo mismo vale también para los habitantes del país cuando hablan de Abraham. Pero una conclusión me parece clara: las tradiciones sobre el pasado de Israel han sido transmitidas porque eran "útiles".

Cuando leemos el Pentateuco, conviene por lo tanto preguntarse para qué han servido y sirven aún las tradiciones que han sido puestas por escrito después de tanto tiempo. 


\section{El segundo Isaías (Is 40-55; primer retorno alrededor y después del 538 a.C.) ${ }^{4}$}

Del segundo Isaías podemos hablar largamente. Pero un punto me parece más importante que los otros. En el segundo Isaías encontramos por primera -y única vez- alusiones a los tres grandes bloques del Pentateuco. Primero, el segundo Isaías habla de creación y de diluvio (Gn 1-11); segundo, menciona dos veces el nombre de Abraham y la segunda vez añade incluso el nombre de Sara (Is 41,8; 51,2); por último, tenemos numerosos textos que hablan del éxodo y de los milagros ocurridos en el desierto. En Isaías 40-55 encontramos por lo tanto no sólo elementos del Pentateuco sino elementos de las tres grandes partes que lo constituyen. Los ladrillos para la construcción del Pentateuco están aquí; al menos, los principales ladrillos. Sólo faltan el cemento para unirlos y el material de acabado para completar la obra.

\subsection{Yhwh, creador y Señor del universo}

El primer tema importante tratado a menudo en el segundo Isaías es la afirmación de un Dios creador y señor del universo. Este Dios es Yhwh, Dios de Israel. Sin entrar en demasiados detalles y en largas discusiones, podemos afirmar que, en el segundo Isaías, aparece en la Biblia, por primera vez de manera clara e indiscutible la idea de un solo Dios, creador de todo el universo. ¿Cómo surgió esta idea en el mundo bíblico? Una razón simple es que era necesario releer toda la historia de Israel a la luz de los eventos internacionales de la época. El segundo Isaías comprende que la suerte de Israel depende de la historia de todas las naciones. La conquista de Babilonia por parte de Ciro, rey de Persia, es vista como fruto de un designio divino que tiene como objetivo permitir el retorno de Israel desde el exilio. El Dios de Israel, Yhwh, es el Dios que guía la historia universal y que comanda a todas las naciones. Es por lo tanto el creador y el señor de todo el universo. Diversos son los textos que afirman esto (cf. sobre todo Is 40,12-31; 44,24; 45,7.12-13.18). El segundo Isaías es también el escrito que más usa el verbo "crear" (en hebreo, bārā': Is 40,26.28; $41,20 ; 42,5 ; 43,1.7 .15 ; 45,7.8 .12 .18 ; 48,7 ; 54,16)$. Entre los elementos importantes, notamos que el mismo Dios crea el universo y la humanidad $(45,12)$.

\footnotetext{
${ }^{4}$ Cuando hablo del segundo Isaías, entiendo la obra sin presuponer la existencia de un solo autor. La cuestión es muy debatida hoy.
} 
Encontramos también en el segundo Isaías que usa un término que aparece en Gn 1,2 para describir el caos primordial: tōhû (cf. Is 44,9; 45,18.19). El caos, Israel lo experimentó cuando Jerusalén fue destruida y durante el exilio (cf. Jer 4,23). Caos y creación son dos polos antitéticos de la acción divina. Por último, el segundo Isaías habla del Edén, palabra clave del segundo relato de la creación (Gn 2-3; cf. Is 51,3).

El segundo Isaías habla también de Noé en 54,9:

Será para mí como en tiempos de Noé: como juré que no pasarían más las aguas de Noé sobre la tierra, así he jurado que no me irritaré más contra ti ni te amenazaré.

Podemos pensar que es precisamente en aquel período que el relato del diluvio, muy conocido en Mesopotamia, haya hecho su entrada en la tradición de Israel y que Noé se haya convertido en el héroe del diluvio bíblico. De nuevo, es necesario leer el destino de Israel como un evento de dimensión cósmica.

\subsection{Abraham $(41,8 ; 51,2)$}

El patriarca Abraham es nombrado sólo dos veces, mientras encontramos más a menudo el nombre de Jacob en Is 40-55. Jacob, sin embargo, designa más bien al pueblo que al patriarca $(40,27 ; 41,8.14 .21 ; 43,1.22 \ldots)$. La primera mención de Abraham es muy concisa. El oráculo habla de Abraham amigo de Dios $(41,8)$, después de haber citado a Jacob/Israel. Podemos decir que el segundo Isaías busca crear una unidad nueva del pueblo poniendo juntos a Jacob y a Abraham. Pero no tenemos aún la famosa genealogía que hace a Abraham el abuelo de Jacob.

El segundo texto es más interesante porque es más detallado (Is 51,2):

Mirad a Abraham, vuestro padre, y a Sara, que os dio a luz; pues uno solo era cuando lo llamé, pero le bendije y le multipliqué.

El texto no hace sino recordar lo de Ez 33,24. Sin embargo, hay una diferencia considerable entre los dos textos. En Ezequiel son los habitantes de las ruinas, aquellos que permanecen en el país, los que invocan el nombre de Abraham para justificar sus prerrogativas. En Is 51,2, por el contrario, es el mismo Yhwh quien habla. El oráculo tiene como objetivo alentar al pueblo en un momento difícil.

Jerusalén está en ruinas y el país es un desierto. Los habitantes son pocos. Dios dice: Sí, el Señor conforta a Sion, conforta todas sus ruinas, transforma su desierto como el Edén y su estepa como el jardín del Señor. Júbilo y alegría se encontrarán en ella, acción de gracias al son de la música. (Is 51,3) 
Parece precisamente que el segundo Isaías retoma los temas presentes en Ez 33,24, no para condenar al pueblo y decir que podrá heredar la tierra sólo si observa la ley sino para volver a dar esperanza a un pueblo desconsolado. Los tiempos han cambiado. Ezequiel debía justificar la ruina de Jerusalén, el segundo Isaías busca animar su reconstrucción. En ambos casos aparece la figura de Abraham que es de todos modos una figura central para los habitantes de Jerusalén y de la tierra de Judá.

El texto de Is 51,2, usa también una palabra importante para nuestra comprensión del Pentateuco: la "bendición". No señala a la tierra, como Ezequiel, sino a la numerosa descendencia, otro tema que estará presente en el ciclo de Abraham (Gn 12-25).

La comparación entre Ez 33,24 e Is 51,2 es instructiva. Nos muestra una vez más que las tradiciones pueden ser interpretadas de maneras muy diversas según las circunstancias. En otras palabras, están abiertas.

Concluyamos diciendo que para el segundo Isaías la figura de Abraham tiene su importancia. Pero no habla de Isaac, su hijo, ni hace de Jacob su nieto. Abraham y Jacob son aún dos figuras separadas.

\section{3. Éxodo y desierto}

El segundo Isaías habla a menudo del éxodo, pero sobre todo con alusiones y en un lenguaje poético. Habla también del desierto y, esta vez, el desierto viene a ser el lugar de numerosos milagros. No citaré todos los textos porque exigirían cada tanto una explicación pormenorizada. Me contento con los textos principales.

Entre los textos más citados a menudo podemos enumerar Is 41,18 ; 43,$20 ; 48,21 ;$ cf. 37,6-7. En realidad es necesario decir que el segundo Isaías describe el retorno del exilio a través del desierto de Siria. El viaje emprendido por los exiliados que regresan evoca imágenes del primer éxodo y de la marcha por el desierto. El primer texto es sintomático (Is 41,17-20):

\footnotetext{
${ }^{17}$ Los humildes y los pobres buscan agua, pero no hay nada. La lengua se les secó de sed. Yo, Yahveh, les responderé, Yo, Dios de Israel, no los desampararé. ${ }^{18}$ Abriré sobre los calveros arroyos y en medio de las barrancas manantiales. Convertiré el desierto en lagunas y la tierra árida en hontanar de aguas. ${ }^{19}$ Pondré en el desierto cedros, acacias, arrayanes y olivares. Pondré en la estepa el enebro, el olmo y el ciprés a una, ${ }^{20}$ de modo que todos vean y sepan, adviertan y consideren que la mano de Yahveh ha hecho eso, el Santo de Israel lo ha creado.
}

Es bastante claro que el texto describe una transformación del desierto delante de quienes retornan del exilio. El desierto se transforma en una tierra de manantiales y de torrentes de agua. En lugar de la estepa, Dios 
hace crecer un bosque. Las imágenes son similares a aquellas que encontramos, por ejemplo, en Gn 2 donde Dios planta un jardín donde había primero sólo una tierra árida y pelada. El v. 20 utilizará incluso el verbo "crear" (bāa $r \bar{a})$. El texto describe en verdad una "nueva creación" o la manifestación del poder de Dios creador. Es difícil ver una alusión clara y precisa a un relato de Éxodo o de Números en Is 41,17-20. Podemos decir, a lo sumo, que el mismo Yhwh, Dios de Israel, interviene de manera similar en Is 41 y en Éxodo - Números para crear condiciones de vida en el desierto. Lo mismo vale para Is 43,19-21:

${ }_{19}$ Pues bien, he aquí que yo lo renuevo: ya está en marcha, ¿no lo reconocéis? Sí, pongo en el desierto un camino, ríos en el páramo. ${ }^{20}$ Las bestias del campo me darán gloria, los chacales y las avestruces, pues pondré agua en el desierto (y ríos en la estepal para dar de beber a mi pueblo elegido. ${ }^{21}$ El pueblo que yo me he formado contará mis alabanzas.

También en este caso, Yhwh, el Dios de Israel demuestra ser el creador y el Señor del universo. Como creador, puede mandar a la naturaleza y hacer brotar agua en el desierto. Es también el Señor de los animales, sobre todo de los animales salvajes, un tema frecuente en el Cercano Oriente antiguo. Dios es capaz de ocuparse de su pueblo y refrescarlo en el desierto. Se trata ciertamente del pueblo que retorna del exilio, no del Israel del éxodo.

El tercer texto es diverso y permite llegar a conclusiones más seguras sobre los nexos entre el segundo Isaías y los relatos de Éxodo - Números. Se trata de Is 48,20-21:

${ }^{20}$ ¡Salgan de Babilonia! ¡Huyan de los Caldeos! ¡Anuncien con voz de júbilo, háganlo saber, proclamen hasta el extremo de la tierra, digan: Yahveh ha rescatado a su siervo Jacob! ${ }^{21}$ No padecieron sed en los sequedales a donde los llevó; hizo brotar para ellos agua de la roca. Rompió la roca y corrieron las aguas.

El texto describe una vez más -sin ninguna duda posible- el retorno del exilio. Pero esta vez, el texto isaiano usa imágenes que evocan un milagro narrado dos veces en el Pentateuco, en Ex 17,1-7 y en Nm 20,1-13. Esta vez, el agua brota de una "roca", en hebreo șûr (Is 48,21; cf. Ex 17,6; Nm 20,8.10.11 utiliza otra palabra, "pared rocosa", sela'). De todos modos la cercanía es inevitable. ¿Pero cuál es el nexo entre Isaías 48,21 y Ex 17,1-7? No es fácil establecerlo con certeza. Pero cabe hacer notar un elemento: Is 48,21 no habla de Moisés quien, en Ex 17,6 golpea la roca para hacer brotar el agua. Si el autor del texto isaiano hubiese conocido el relato de Ex 17,1-7, habría hablado del rol de Moisés en el milagro. Es al menos razonable pensar de ese modo. No lo hace y podemos afirmar con un buen 
grado de certeza que no conocía el relato que leemos ahora en Ex 17,1-7. Probablemente conoce una tradición sobre los milagros realizados por Yhwh en el desierto. Más tarde se introducirá la mediación de Moisés y, en ciertos casos, de Aarón.

El texto de Isaías nos permite por tanto proponer una hipótesis sobre la génesis de los relatos bíblicos del desierto. Existían al inicio tradiciones sobre el poder de Dios creador y sus milagros realizados por Yhwh en el desierto. Los relatos, con toda probabilidad, fueron reelaborados una vez compuesto el Pentateuco. En este momento la figura de Moisés llega a ser central. Es él quien se convierte en el mediador en muchos acontecimientos esenciales, tales como la salida de Egipto y los milagros realizados en el desierto. ¿Por qué Moisés toma importancia? Los motivos son muchos. Uno es porque hay oposición entre diversas figuras humanas, por ejemplo entre los patriarcas y Moisés, como aparece en Os 12. Un segundo motivo se debe buscar, pienso, en la desaparición de la monarquía. En el período pos-exílico llega a ser un imperativo sustituir la figura del rey con otra figura, más antigua y más cercana a Dios. Un tercer motivo está ligado - probablemente- al desarrollo de la teología pos-exílica. Dios está cada vez más lejano y la necesidad de encontrar mediaciones entre el mundo divino y el mundo humano se siente cada vez más. Por último, es bastante probable que hubiera muchos contrastes y conflictos durante el período pos-exílico; pero todos hablaban en nombre del mismo Yhwh. El problema no era por lo tanto la fe en Yhwh, sino la forma de fe y de religión a adoptar. Moisés, en este contexto, representa una forma de religión, la que se logró imponer y que está ligada, grosso modo, a la ley y a la alianza.

Conclusión. El segundo Isaías es un anillo importante en la cadena de la tradición que podemos localizar en los libros proféticos. El libro yuxtapone elementos que están contrapuestos en otros libros, como por ejemplo los patriarcas y el éxodo. En el segundo Isaías, Abraham es una figura positiva, invocada para despertar la esperanza. De un modo análogo el profeta se vuelve a la experiencia del éxodo. Estamos en un período en el cual se busca unir todas las fuerzas para reconstruir la ciudad. Se dejan de lado las oposiciones y los contrastes, al menos temporalmente.

La consecuencia es evidente en lo que respecta a la formación del Pentateuco. Para retomar la imagen usada al comienzo de este apartado, muchos ladrillos del futuro Pentateuco ya han sido recogidos. Pero aún no han entrado en una construcción única. Falta agregar también el cemento. Para gran parte del edificio, el cemento será un personaje, aún ausente en las profecías de Is 40-55: Moisés. 


\section{El tercer Isaías - Is 56-66 (después de la reconstrucción del templo en el 520 a.C., aproximadamente)}

La colección de oráculos que encontramos en Is 56-66 ha sido atribuida de vez en cuando a un profeta llamado Trito-Isaías. Es muy probable que los oráculos no hayan sido redactados por la misma persona. La situación de la época del segundo Isaías ha cambiado. Los conflictos aparecen más claramente y hay grietas en la comunidad que se reconstruye en Jerusalén y en la provincia de Judea.

Hemos leído el texto de Is 63,7-14 que opone fuertemente a los patriarcas Abraham y Jacob de una parte y a Moisés de la otra. No vale la pena repetir cuanto ya se ha dicho. Noto sólo un aspecto: Abraham y Jacob son citados juntos y esto significa que, quizás, se está constituyendo un "corpus" narrativo en torno a los diversos patriarcas (cf. también Mi 7,20). No tenemos aún la genealogía bien clara de Abraham, Isaac y Jacob. Pero encontramos, a Abraham y a Jacob, uno al lado del otro. La conclusión puede sorprender. Pero debemos, para ser honestos, decir que el Pentateuco que conocemos es -después de estas indagaciones- una construcción mucho más tardía de cuanto se puede pensar y de cuanto se ha pensado por mucho tiempo.

\section{La Ley y los Profetas}

Hemos hallado hasta ahora más que nada elementos que forman parte de las grandes tradiciones narrativas del Pentateuco: patriarcas, éxodo, desierto. Hemos hablado de la ley sólo a propósito de Ez 20. Conviene ensanchar todavía más el radio de nuestra investigación e interrogar a los libros proféticos, en este último apartado, sobre sus relaciones con el mundo de la ley. Los profetas insisten a menudo sobre el derecho y la justicia. El hecho es bien notable. Pero mi pregunta es más precisa. Deseo saber si los profetas -o los libros proféticos-conocen las colecciones de leyes que encontramos ahora en el Pentateuco, vale decir el decálogo, el código de la alianza (Ex 21-23), el decálogo cultual (Ex 34), la ley de santidad (Lev 17-26), el código del Deuteronomio (Dt 12-26) y las otras pequeñas colecciones de leyes presentes sobre todo en el libro de los Números. Hay muchos problemas al respecto y no puedo tratarlos todos en pocas líneas. Existen vínculos bastante estrechos, por ejemplo, en la llamada torá de Ezequiel (Ez 40-48) y diversos textos del éxodo (25-31; 35-40), del Levítico y del libro de los Números, en particular en lo que respecta a la organización del culto y las jerarquías sacerdotales. Ciertamente estamos en el período pos-exílico y asistimos a las últimas fases de la formación del Pentateuco. 
En los períodos más antiguos, hay mucho menos rasgos de este tipo. Los contactos son esporádicos y poco claros. El hecho puede sorprender, pero no debemos olvidar que, en el mundo antiguo, el derecho escrito tenía una función bien diversa de la que puede tener hoy. Las colecciones de leyes eran más bien monumentos literarios que códigos para consultar y, sobre todo, para aplicar. Los jueces "hacían" las leyes, no aplicaban un código. Las colecciones de leyes escritas son, para decirlo en pocas palabras, obras literarias que tienen como objetivo afirmar la existencia de un derecho y testimoniar su origen. El famoso código de Hammurabi, por ejemplo, testimonia un hecho esencial: el poder de Hammurabi. Es él y solo él quien reina y hace reinar el derecho en su inmenso imperio. La estela original sobre la cual fue grabado el código de Hammurabi ha sido encontrada en Elam, al oriente de Mesopotamia (actual Irán). ¿Por qué? Porque los Elamitas invadieron Babilonia, la derrotaron y tomaron como parte de su botín la estela, para demostrar que ahora no debían obedecer más a sus dirigentes de antes. Hammurabi y los babilonios ya no mandaban más. La estela -y el código allí grabado- tenía un valor simbólico y político no indiferente.

Para volver a nuestro tema, no debemos por lo tanto asombrarnos de que cuando los profetas tratan problemas de justicia y derecho la emprenden sobre todo contra los jueces y no citan textos legislativos. El derecho estaba en las manos de los jueces y no contenido en los códigos o en las colecciones de leyes.

Hay, sin embargo, algunos textos que valen la pena ser citados porque nos permiten percibir que existía una cierta divergencia entre la tradición jurídica representada por los jueces -y no olvidemos que, en la Biblia y en el mundo antiguo, el juez es sencillamente el dirigente político- y el derecho consuetudinario vigente en la población. Hay conflictos, tanto ayer como hoy, entre el derecho impuesto por las autoridades y el derecho que defiende la población. Los profetas están, con frecuencia, del lado de la población.

\subsection{Ley y derecho (Is 10,1-2; Jr 8,8-9)}

Dos textos particulares son relevantes en este campo: Is 10,1-2; Jr 8,8 . Vale la pena detenerse un instante en los dos textos. En ambos casos vemos que el profeta la emprende con las leyes establecidas por algunos jueces y defiende otra idea del derecho. Is 10,1-2:

\footnotetext{
${ }^{1}$ ¡Ay! los que promulgan decretos inicuos, y los escribientes que escriben vejaciones, ${ }^{2}$ excluyendo del juicio a los débiles, atropellando el derecho de los míseros de mi pueblo, haciendo de las viudas su botín, y despojando a los huérfanos.
} 
Volvemos a encontrar la misma actitud en Jr 8,8-9:

${ }^{8}$ ¿Cómo dicen ustedes: «Somos sabios, y poseemos la Ley de Yahveh?» Cuando es bien cierto que en mentira la ha cambiado el cálamo mentiroso de los escribas. ${ }^{9}$ Los sabios pasarán vergüenza, serán abatidos y presos. He aquí que han desechado la palabra de Yahveh, y su sabiduría ¿de qué les sirve?

Los textos no son fáciles de interpretar porque los dos profetas no especifican de cuáles leyes se trata. Algunos exegetas han querido ver en el primer caso una alusión al código de la alianza (Ex 21-23) y en el segundo una insinuación a la ley del Deuteronomio (Dt 12-16). Pero los profetas arremeten menos contra el derecho escrito que contra quien escribe leyes injustas o hace ejercicio inicuo de la justicia. No basta, para los profetas, ocupar un puesto oficial y ejercer el poder. No todo es permitido a quien tiene la capacidad de "escribir" leyes. Además, no basta un derecho escrito o leyes escritas para hacer reinar la justicia o garantizar un ejercicio equitativo e imparcial de la justicia.

De todos modos los dos textos dan testimonio también de la actividad de escribas encargados de la redacción de textos legislativos. Isaías habla de "decretos" $(h \bar{o} q)$, Jeremías incluso de "ley" (tôrâ). Son por lo demás personas que pertenecen a la corte real o a la administración que depende del rey. Es necesario buscar allí los orígenes de las colecciones de leyes que han entrado en la composición del Pentateuco.

Permanece una pregunta: ¿A cuál tipo de derecho se refieren los profetas cuando critican las leyes emanadas de los "escribas" de la corte real? Dos textos dan testimonio de la existencia de un derecho más importante que las leyes escritas. De hecho, la Biblia distingue entre "derecho" y "ley". El derecho está inscrito en la conciencia individual y colectiva, no depende de las autoridades, no tiene necesidad de ser promulgado y no puede ser abrogado, no está ligado ni a un territorio ni a un grupo de personas.

Con frecuencia, cuando los profetas hablan de "derecho y justicia", invocan el derecho fundamental sin el cual la sociedad no puede existir. Los profetas se hacen abogados de un derecho del cual las autoridades, el rey en primer lugar, son los custodios (cf. Sal 72,1-2). ¿Pero dónde encontramos expresiones de este derecho? Me parece que hay dos textos que hablan de él de manera explícita: Os 4,1-4 y Jr 7,8-10.

He aquí el primer texto en el cual reconocemos elementos de la segunda tabla del decálogo, aquella que contiene los deberes hacia el prójimo (Os 4,1-4):

${ }^{1}$ Escuchen la palabra de Yahveh, hijos de Israel, que tiene pleito Yahveh con los habitantes de esta tierra, pues no hay ya fidelidad ni amor, ni conocimiento de Dios en esta tierra; ${ }^{2}$ sino perjurio y mentira, asesinato y robo, 
adulterio y violencia, sangre que sucede a sangre. ${ }^{3}$ Por eso, la tierra está en duelo, y se marchita cuanto en ella habita, con las bestias del campo y las aves del cielo; y hasta los peces del mar desaparecen. ${ }^{4}$ ¡Pero nadie pleitee ni reprenda nadie, pues sólo contigo, sacerdote, es mi pleito!

El profeta Oseas habla en este texto no de ley escrita, sino de lealtad ('emet, "verdad", "honestidad", "sinceridad"), de amor (hesed, "fidelidad", "amor fiel") y de conocimiento de Dios (da'at yhwh). Son términos que podemos identificar con el "derecho" del cual hace poco hablé, es decir, del derecho que es fundamento de toda sociedad y de toda legislación. Pero, el profeta traduce más bien los términos abstractos en términos más concretos en el versículo siguiente: allí donde desaparecen los fundamentos de la justicia aparecen grandes abusos y atropellos: el falso testimonio que conduce frecuentemente a la ejecución de un inocente (cf. el caso de Nabot en 1 Re 21); el homicidio, el hurto, el adulterio. Se ve que se trata de derechos fundamentales de la persona, en particular la vida (la "sangre"), una vida decente y digna, y el matrimonio.

El segundo texto es más breve (Jr 7,8-10):

${ }^{8}$ Pero he aquí que ustedes se fían de palabras engañosas que de nada sirven, ${ }^{9}$ para robar, matar, adulterar, jurar en falso, incensar a Baal y seguir a otros dioses que no conocían. ${ }^{10}$ Luego vienen y se paran ante mí en esta Casa llamada por mi Nombre y dicen: «jestamos salvos!», para seguir haciendo todas esas abominaciones.

Volvemos a encontrar en lo esencial los delitos denunciados por Oseas: robar, asesinar, cometer adulterio y jurar en falso. Además, y es un punto original en Jeremías, encontramos delitos en el campo religioso: el culto a dioses extranjeros. Aparece por lo tanto un elemento que formará parte de la primera tabla del decálogo, aquella que contiene los deberes hacia Dios. Estamos sobre el camino que conducirá a la composición -que podemos colocar en el período pos-exílico- del decálogo de Ex 20,1-17 y Dt 5,6-21.

Desde el punto de vista del derecho del Antiguo Testamento y del Pentateuco en particular, es interesante notar que el Decálogo precede toda la legislación, tanto en el caso del Éxodo como en el caso del Deuteronomio. El Decálogo contiene una serie de principios esenciales del derecho que Oseas y Jeremías probablemente han retomado en una tradición anclada en la experiencia del pueblo y, quizás, transmitida de generación en generación a través de la educación de los hijos dentro de la familia y del clan. Se llama la atención en esta tradición contra los excesos y los abusos de una sociedad injusta. El hecho de que el Decálogo sea ahora el verdadero fundamento del derecho bíblico es, ciertamente, un fruto de la 
predicación de los profetas que, como hemos visto, han arremetido contra los miembros de la clase dirigente que no actuaba, y legislaba sin tener en cuenta el "derecho" fundamental del pueblo, inscrito en su conciencia y en su tradición.

El Decálogo, en Ex 20 así como en Dt 5, es proclamado antes del resto de la legislación y, según algunos textos por lo menos, directamente por Dios al pueblo. Es un modo de indicar, en la Biblia, que no puede ser modificado por el pueblo. Es derecho "divino" y no forma parte de la legislación que se puede interpretar o modificar. Son principios absolutos -a pesar de que, como podemos ver comparando las dos versiones de Éxodo y de Deuteronomio- pueden existir diversas formulaciones de los mismos principios. La formulación es secundaria, los principios son importantes.

\section{Conclusión}

Nuestro recorrido ha sido largo, quizás demasiado largo. Una sola palabra al final de esta larga investigación: hemos encontrado en los profetas muchos elementos del Pentateuco, pero normalmente esparcidos y no unificados. Por otra parte, y es mi punto más importante, sobre el cual desearía insistir al final: no encontramos por ninguna parte en los profetas una citación explícita de un texto del Pentateuco, cosa que sí encontramos por ejemplo en los libros de Esdras y de Nehemías (cf. Esd 4,7; Ne 6,6; 7,5; 8.14; 13,1; cf. también la expresión: "como está escrito" en Esd 3,2.4; Ne 8,$15 ; 10,35.37$; y en los textos tardíos de Jos 8,31; 1 Re 2,3; 2 Re 14,6; 23,$21 ; 2$ Cr 23,18; 25,4; 30,5.18; 31,3; 35.12.26).

Sólo en una época muy tardía, cuando fueron escritos los libros de Esdras y de Nehemías, o los libros de las Crónicas, podemos estar seguros de que existiese un Pentateuco escrito. Quizás no aún nuestro Pentateuco, pero al menos una obra muy similar a aquella. Antes, existían textos separados, colecciones de relatos, y colecciones de leyes, pero no aún una obra completa y organizada en cinco libros. Cómo se llegó a este resultado es en verdad otra historia.

\section{Breve bibliografía}

Baltzer, D., Ezechiel und Deuterojesaja. Berührungen in der Heilserwartung der beiden grossen Exilspropheten, BZAW 121, Walter de Gruyter Berlin - 1971.

Daniels, D.R., Hosea and Salvation History: The Early Traditions of Israel in the prophecy of Hosea, BZAW 191, Berlin - 1990. 
Kreuzer, S., Die Frühgeschichte Israels in Bekenntnis und Verkündigung des Alten Testaments, BZAW 178, Berlin - 1989.

NeEF, H.-D., Die Heilstraditionen Israels in der Verkündigung des Propheten Hosea, BZAW 169, Berlin - 1987.

Perlitt, L., Bundestheologie im Alten Testament, WMANT 36; Neukirchener - Neukirchen-Vluyn - 1969.

Vollmer, J., Geschichtliche Rückblicke und Motive in der Prophetie des Amos, Hosea und Jesaja, BZAW 119, Berlin - 1971.

Wellhausen, J., Prolegomena zur Geschichte Israels, Berlin - 1878, 18832, $1899^{5}$; traducción inglesa: Prolegomena to the History of Israel, A. \& C. Black - Edinburgh, 1885.

JEAN-Louis SkA

ROMA

ska@biblico.it 